\title{
Die - 2 rue des Fabriques
}

Jean-Marc Lurol

URL : http://journals.openedition.org/adlfi/14771

ISSN : 2114-0502

Éditeur

Ministère de la culture

Référence électronique

Jean-Marc Lurol, «Die - 2 rue des Fabriques », ADLFI. Archéologie de la France - Informations [En ligne], Rhône-Alpes, mis en ligne le 20 mai 2015, consulté le 19 avril 2019. URL : http://

journals.openedition.org/adlfi/14771

Ce document a été généré automatiquement le 19 avril 2019

(c) Ministère de la Culture et de la Communication, CNRS 


\title{
Die - 2 rue des Fabriques
}

\author{
Jean-Marc Lurol
}

Code INSEE de la commune : 26113

Lien Atlas (MCC) :

http://atlas.patrimoines.culture.fr/atlas/trunk/index.php?

ap_theme=DOM_2.01.02\&ap_bbox=5.314;44.711;5.461;44.792

1 Le diagnostic archéologique réalisé du 2 au 3 mai 2013 a été déclenché par un projet de construction de plusieurs bâtiments sur la parcelle AX 133, localisée en zone archéologique sensible. L'ouverture de quatre sondages a permis, d'une part, de réaliser une analyse des dépôts sédimentaires supérieurs de ce secteur sur plus de $2 \mathrm{~m}$ d'épaisseur et, d'autre part, de mettre au jour deux tronçons de murs. Dans le fond des sondages, des colluvions paraissent naturelles et ne contiennent pas d'artefact. Par-dessus se mettent en place des dépôts de sédiments, plus ou moins anthropisés (tuiles, céramique), dont l'origine est à la fois le résultat de colluvionnements et aussi d'apports volontaires de remblai. Le mobilier archéologique apparaît dispersé dans les couches; il est composé de 19 tessons de céramique (16 tessons d'époque gallo-romaine, 2 tessons du Moyen Âge et un tesson non déterminé). Il n'existe aucun niveau de sol en place.

2 Les deux tronçons de murs, orientés nord-ouest/sud-est, retrouvés entre 1,40 et 1,50 m de profondeur dans le sondage 3 (alt. NGF Mr. $9=408,85 \mathrm{~m}$ et Mr. $10=408,65 \mathrm{~m}$ ), peuvent appartenir à un même ensemble (bâtiment?). Leur datation n'est pas reconnue. 
INDEX

Index géographique : Rhône-Alpes, Drôme (26), Die

Mots-clés : mur, céramique

operation Opération préventive de diagnostic (OPD), 2013 - n OA : 2211264

Index chronologique : Gallo-romain, Moyen Âge

\section{AUTEURS}

JEAN-MARC LUROL

Inrap 